\title{
In vitro antihepatocellular carcinoma activity of secondary metabolites of Centaurea kilaea Boiss.
}

\author{
Turgut ŞEKERLER $1 *$ (D) , Ali ŞEN 2 (D), Leyla BİTíş 2 (D), Azize ŞENER 1 (D) \\ 1 Department of Biochemistry, Faculty of Pharmacy, Marmara University, Haydarpaşa 34668 İstanbul, Turkey \\ 2 Department of Pharmacognosy, Faculty of Pharmacy, Marmara University, Haydarpaşa 34668 İstanbul, Turkey. \\ * Corresponding Author. E-mail: turgut.sekerler@marmara.edu.tr (T.S); Tel. +90-216-777 5200.
}

Received: 25 February 2020 / Revised: 04 June 2020/ Accepted: 14 June 2020

\begin{abstract}
The aim of this study was to investigate in vitro cytotoxic effects of previously isolated compounds (taraxasterol, salvigenin, 3'-O-methyleupatorin, oleanolic acid, jaceosidin and pectolinarigenin) from Centaurea kilaea chloroform extract on hepatocellular carcinoma cell lines, HepG2 and Hep3B, as well as to evaluate the effect on the normal cell line, NIH3T3. In vitro antihepatocellular carcinoma activity of compounds was assessed by MTT method. All compounds except pectolinarigenin caused more inhibition on HepG2 rather than Hep3B. Among these compounds, it was found that Jaseosidin had the highest anticancer activity with $\mathrm{IC}_{50}$ values of $137.66 \mu \mathrm{g} / \mathrm{mL}$ and $147.66 \mu \mathrm{g} / \mathrm{mL}$ on the HepG2 and Hep3B cell lines, respectively. 3'-O-methyleupatorin showed the second highest cytotoxicity with $\mathrm{IC}_{50}$ values of $151.98 \mu \mathrm{g} / \mathrm{mL}$ and $159.24 \mu \mathrm{g} / \mathrm{mL}$ against the HepG2 and Hep3B cell lines, respectively. The results indicated that Jaseosidin and 3'-O- methyleupatorin, had the best antiproliferative activity against hepatocellular carcinoma cell lines. Also, according to our best knowledge, this study is first report on antihepatocellular carcinoma activity of Jaseosidin and 3'-O- methyleupatorin.
\end{abstract}

KEYWORDS: Centaurea kilaea; anticancer activity; hepatocellular carcinoma; jaceosidin; 3'-O-methyleupatorin

\section{INTRODUCTION}

Liver cancer is one of the major diseases that cause mortality and morbidity worldwide. It affects people's quality of life and causes society to suffer material and moral damage [1].

There are many risk factors under hepatocellular carcinoma. Viral factors such as hepatitis B and hepatitis C, excessive alcohol consumption and fatty liver are among these factors. Aflatoxins, the product of Aspergillus strains, are found in some dietary foods such as corn, peanuts, soybeans, are also another risk factor. Less determining factors include hereditary hemochromotosis, a-1 antitrypsin deficiency, autoimmune hepatitis and some psoriasis [2].

Hepatocellular carcinoma developing from liver cells constitutes $85-90 \%$ of primary liver cancers. Surgical treatment, regional cancer treatment, radiotherapy and chemotherapy are used in the treatment of hepatocellular carcinoma, but there is still no definitive treatment [3]. The toxic effects of chemotherapy and the resistance of cancer cells to the chemical agents used have induced the investigation of alternative treatment methods. Natural plant products may offer a solution [4]. Studies are ongoing on a number of methods such as isolation of active molecules from plants/other natural sources, synthetic chemistry, molecular modeling for drug discovery [5]. The number of scientific studies on the anticancer properties of Centaurea species has been increasing recently. Orabi et al. (2013) suggested that C. aegyptiaca ethanol extract had anticancer effect on the hepatocellular carcinoma cell line [6]. Sekerler et al. (2018) reported that chloroform extracts prepared from the aerial parts of some Centeura species significantly inhibited the growth of HepG2 cells [7]. Ahmed et al. (2014) found that the flavonoids isolated from the C. scoparia species had an important anticancer activity on HepG2 [8]. There are also numerous studies showing that different Centaurea species and their secondary metabolites have significant anticancer effects on different cancer lines $[6,9-14]$. In one of these studies, it was reported that 8a-hydroxy-11a,13-dihydrozaluzanin C isolated from Centaurea aegyptiaca ethanol extract showed a potential cytotoxic activity against larynx carcinoma cell line [6]. Chicca et al. (2011) found that aguerin B from C. deflexa had an anti-proliferative activity against human pancreatic and colonic cancer cells [9]. In another study, Csapi et al. (2010) revealed that C. arenaria

How to cite this article: Şekerler T, Şen A, Bitiş L, Şener A. Antihepatocellular carcinoma activity of secondary metabolites of Centaurea kilaea Boiss. J Res Pharm. 2020; 24(4): 479-486. 
chloroform extract and its secondary metabolites (apigenin, eupatorin, arctigenin, arctiin, matairesinol and cnicin) had potent growth inhibitory activities on cervix adenocarcinoma (HeLa), breast adenocarcinoma (MCF7) and skin epidermoid carcinoma (A431) cells [10].

Based on these findings, in this study, we aimed to investigate the anticancer effect of four flavonoids, salvigenin, 3'-O- methyleupatorin, jaceosidin and pectolinarigenin along with two triterpenes, taraxasterol and oleanolic acid previously obtained from Centeura kilaea Boiss. chloroform extract by our team [Figure 1, 12] on HepG2 and Hep3B hepatocellular carcinoma cell lines. Anticancer activities of taraxasterol on HepG2 cell line, oleanolic acid on Hep3B and HepG2 cell lines and pectolinarigenin on Huh-7D12 cell line were previously reported [15-17]. However, this study is the first report on anticancer activity of taraxasterol, salvigenin, 3'-O-methyleupatorin, jaceosidin and pectolinarigenin against HepG2 and/or Hep3B cancer cell lines. In order to evaluate selectivity, the cytotoxic activities of these compounds on NIH3T3 fibroblast cell line, normal cancer cells, were studied.<smiles>C=C1CC[C@]2(C)CC[C@]3(C)C(CCC4[C@@]5(C)CC[C@@H](O)C(C)(C)C5CC[C@]43C)C2[C@@H]1C</smiles><smiles>[R]c1ccc(-c2cc(=O)c3c(O)c([R3])c([R])cc3o2)cc1[R]</smiles>

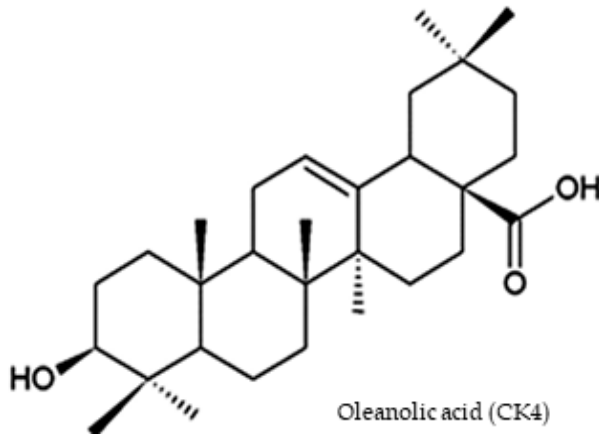

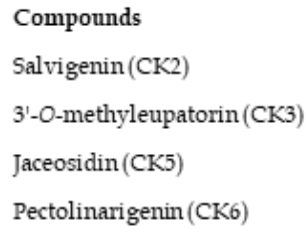

$\begin{array}{cccc}\mathbf{R}_{1} & \mathbf{R}_{2} & \mathbf{R}_{3} & \mathbf{R}_{4} \\ \mathrm{H} & \mathrm{OCH}_{3} & \mathrm{OCH}_{3} & \mathrm{OCH}_{3} \\ \mathrm{OCH}_{3} & \mathrm{OCH}_{3} & \mathrm{OCH}_{3} & \mathrm{OCH}_{3} \\ \mathrm{OCH}_{3} & \mathrm{OH} & \mathrm{OCH}_{3} & \mathrm{OH} \\ \mathrm{H} & \mathrm{OCH}_{3} & \mathrm{OCH}_{3} & \mathrm{OH}\end{array}$

Figure 1. Chemical structures of CK1-CK6.

\section{RESULTS}

The $\mathrm{IC}_{50}$ values of the compounds isolated from Centeura kilaea were given in Table 1. Jaceosidin had the highest toxicity on hepatocellular carcinoma cells when compared to other compounds. $\mathrm{IC}_{50}$ values of the Jaceosidin were found as $147.67 \mu \mathrm{g} / \mathrm{mL}$ and $137.67 \mu \mathrm{g} / \mathrm{mL}$ against Hep3B and HepG2 cell lines, respectively.

Table 1. $\mathrm{IC}_{50}$ values of compounds isolated from Centeura kilaea.

\begin{tabular}{ccc}
\hline Compounds $^{\mathbf{a}}$ & HepG2 cell line & Hep3B cell line \\
\hline & \multicolumn{3}{c}{$\mu \mathrm{g} / \mathrm{mL}$} \\
CK1 & 178.57 & $>500$ \\
CK2 & 165.56 & $>500$ \\
CK3 & 151.98 & 159.24 \\
CK4 & 229.36 & $>500$ \\
CK5 & 137.67 & 147.67 \\
CK6 & 427.35 & 188.47 \\
\hline
\end{tabular}

a $\mathrm{CK} 1, \mathrm{CK} 2, \mathrm{CK} 3, \mathrm{CK} 4, \mathrm{CK} 5$ and CK6 show taraxasterol, salvigenin, 3'-Omethyleupatorin, oleanolic acid, jaceosidin and pectolinarigenin isolated from Centeura kilaea. 
3'-O-methyleupatorin showed the second highest cytotoxic activity with $\mathrm{IC}_{50}$ values of 151.98 and $159.24 \mathrm{\mu g} / \mathrm{mL}$ against Hep3B and HepG2 cell lines, respectively. The compounds were found to be particularly effective against the HepG2 cell line. It was also found that pectolinarigenin with an $\mathrm{IC}_{50}$ value of $427.35 \mu \mathrm{g} / \mathrm{mL}$ against HepG2 cell line, and taraxasterol, salvigenin and oleanolic acid with $\mathrm{IC}_{50}$ values of $>500 \mu \mathrm{g} / \mathrm{mL}$ (for each compounds) against Hep3B cell line had the lowest anticancer effects (Table 1).

Also, the percentage proliferation values of the compounds isolated from Centeura kilaea at $100 \mu \mathrm{g} / \mathrm{mL}$ concentration were shown as the bar graphs in the Figure 2-4. Compared to the control group (without drug exposure), all compounds showed a statistically significant inhibition against HepG2 cell line ( $\mathrm{p}<0.001$ for each compounds). Out of these compounds, jaceosidin exhibited the highest activity with an inhibition rate of $36.3 \%$ (Figure 2). Compared to the control group, three compounds, 3'-O-methyleupatorin, jaceosidin and pectolinarigenin displayed a statistically significant inhibition against Hep3B cell line $(\mathrm{p}<0.01$ for each of the first two compounds, $\mathrm{p}<0.05$ for the last compound). Among these compounds, jaceosidin demonstrated the highest activity with an inhibition rate of $33.9 \%$ (Figure 3). Finally, taraxasterol, salvigenin, 3'-Omethyleupatorin, jaceosidin showed a statistically significant inhibition against NIH3T3 mouse fibroblast cell line compared to the control group ( $p<0.001$ for each compounds). Jaceosidin represented highest cytotoxic activity with an inhibition rate of $49.2 \%$ among these compounds (Figure 4 ).

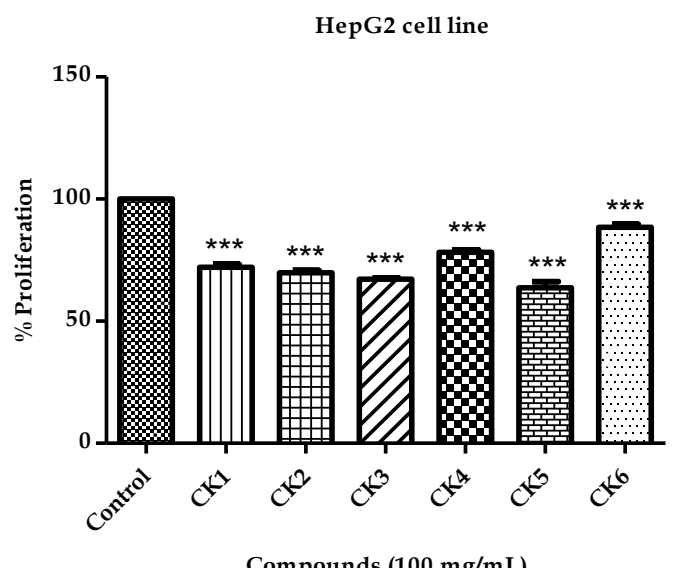

Figure 2. Effects of $100 \mu \mathrm{g} / \mathrm{mL}$ concentration of compounds isolated from C. kilaea against HepG2 cell line. CK1, CK2, CK3, CK4, CK5 and CK6 show taraxasterol, salvigenin, 3'-O-methyleupatorin, oleanolic acid, jaceosidin and pectolinarigenin isolated from Centeura kilaea, respectively. Data were presented as mean \pm standard deviation (SD). ${ }_{* * *} \mathrm{p}<0.001$ versus control group.

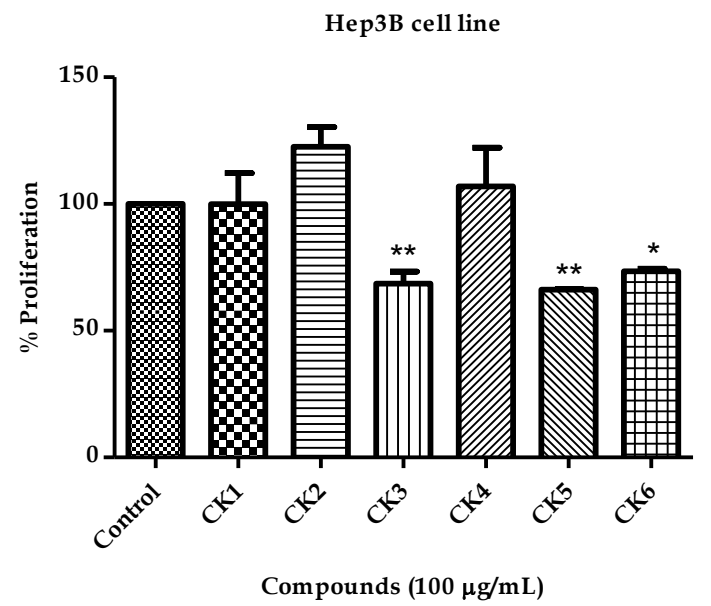

Figure 3. Effects of $100 \mu \mathrm{g} / \mathrm{mL}$ concentration of compounds isolated from C. kilaea against Hep3B cell line. CK1, CK2, CK3, CK4, CK5 and CK6 show taraxasterol, salvigenin, 3'-O-methyleupatorin, oleanolic acid, jaceosidin and pectolinarigenin isolated from Centeura kilaea, respectively. Data were presented as mean \pm standard deviation (SD). ${ }^{*} \mathrm{p}<0.05,{ }^{* *} \mathrm{p}<0.01$ versus control group. 


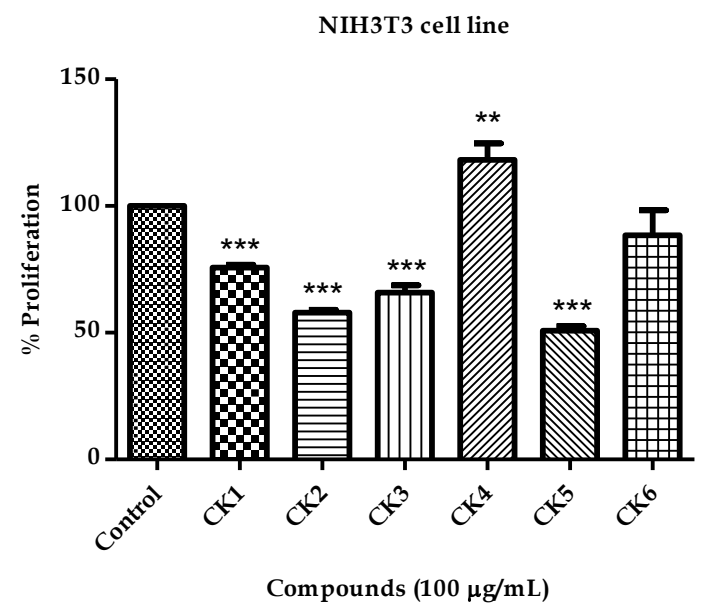

Figure 4. Effects of $100 \mu \mathrm{g} / \mathrm{mL}$ concentration of compounds isolated from $C$. kilaea against NIH3T3 cell line. CK1, CK2, CK3, CK4, CK5 and CK6 show taraxasterol, salvigenin, 3'-O-methyleupatorin, oleanolic acid, jaceosidin and pectolinarigenin isolated from Centeura kilaea, respectively. Data were presented as mean \pm standard deviation (SD). ${ }^{* *} p<0.01,{ }^{* * *} p<0.001$ versus control group.

\section{DISCUSSION}

Hepatocellular carcinoma ranks fifth in cancer types in terms of morbidity and mortality, affecting about five million people worldwide each year. Systemic chemotherapy is not very effective in terms of survival, and besides, chemical resistance against drugs is one of the important difficulties in this disease. Agents such as paclitaxel, tamoxifen, octreotide or antiandrogens are completely ineffective. From this point of view, it is very important to develop new drug candidate molecules for hepatocellular carcinoma [18].

Centaurea is a genus belonging to the Asteraceae family and represented by about 205 taxa in Turkey [19-21]. Centaurea species contain abundant sesquiterpene lactone and flavonoids [22]. In traditional medicine, Centaurea species are used in the treatment of abscess, skin diseases, fever, menstrual disorders, vaginal candidiasis and also diseases of the liver, kidneys and ulcers [23, 24].

In recent years, some Centaurea species and their secondary metabolites have been reported to have an anticancer effect on various cell lines. Bahmani et al. demonstrated that $C$. albonitens extract enhanced the therapeutic effects of vincristine in leukemic cells [25]. In an another study, the anticancer effect of salograviolide A isolated from C. ainetensis extract was demonstrated on p-53 positive HCT-116 cell lines [26]. In a study by Alper et al., effect on various cancer cell lines of $C$. solstitialis extract was investigated. According to this study, the highest cytotoxic activity was observed in the Hela cell line with an $\mathrm{IC}_{50}$ value of $63.18 \mu \mathrm{g} / \mathrm{mL}$ while the lowest cytotoxic activity was observed in the A549 cell line with an $\mathrm{IC}_{50}$ value of 252.5 $\mu \mathrm{g} / \mathrm{mL}$. However, it was reported that the $\mathrm{IC}_{50}$ value of $75.25 \mu \mathrm{g} / \mathrm{mL}$ was detected in the BEAS2b normal cell line [27]. In a study by Yirtici et al., it was stated that C. fenzlii Reichardt extract had an inhibitory effect on the MCF-7 cell line. According to this study, C. fenzlii Reichardt extract on MCF-7 cell line was reported to have an $\mathrm{IC}_{50}$ value of $45.77 \mu \mathrm{g} / \mathrm{mL}$ [28].

In a study previously conducted by our team, anticancer activities of Centaurea species including C. kilaea on HepG2 cancer cell lines were investigated and it was found out that these species had an important anti-cancer activity [7]. Based on these results, in the present work, it was aimed to determine the effects of previously isolated molecules from C.kilaea on hepatocellular cancer cell lines such as HepG2, Hep3B, and also on NIH3T3 cell line obtained from mouse fibroblasts to evaluate the toxicity of compounds in healthy cells. According to the results, it was found that all of the isolated compounds had an inhibitory effect on the HepG2 cell line compared with the viability rates of the control group. Three out of 6 compounds, 3'-Omethyleupatorin, jaceosidin and pectolinarigenin showed an inhibitory effect on the growth of the Hep3B cell line. The jaceosidin, the most toxic of the isolated molecules, caused an inhibition of $36.32 \%$ in the HepG2 cell line, while leading to an inhibition of 33.86\% in the Hep3B cell line. However, this compound showed toxic effect on healthy cells and caused 49\% inhibition in the NIH3T3 cell line. No studies on the anticancer effects of jaceosidin against HepG2 and Hep3B cancer cell lines have been found in the literature. Although the current study is the first, there are reports that jaceosidin has significant anticancer effects 
against different types of cancer, such as CAOV-3 (human ovarian cancer cell line), SKOV3 (human ovary cancer cell line), HeLa (human cervical cancer cell line), PC3 (human prostate cancer cell), U87 (human glioblastoma cell line), human bladder cancer T24 (human bladder carcinoma cell line) cell lines [29-31]. These results overlap with our current study, confirming the anticancer effect of jaceosidin.

3'-O- methyleupatorin was the second most effective cytotoxic constituent with $\mathrm{IC}_{50}$ values of 151.98 and $159.24 \mathrm{\mu g} / \mathrm{mL}$ against HepG2 and Hep3B cell lines, respectively. Although a study on the anticancer effects on Hela and MCF-7 cell lines of 3'-O- methyleupatorin has been reported in the literature [32], the anticancer activity of this compound against hepatocellular carcinoma cell lines has not been reported to date.

Also, it was observed that most of the active compounds in this study were compounds with flavonoids structure. Kanadaswami et al. (2005) reported that the hydroxylation pattern of the B ring of flavones and flavonols such as luteolin and quercetin played an important role in anticancer activity, especially by inhibiting protein kinase activity and proliferation of cancerous cells [33]. Similarly, when the three compounds with the best activity, 3'-O-methyleupatorin, jaceosidin and pectolinarigenin, were compared with each other in terms of structure-activity relationship, it was observed that the presence of a 4 '-OH group in the $\mathrm{B}$ ring of the molecule such as jaceosidin increased the anticancer activity.

In addition, some of the compounds whose activities have been investigated in the current study have been reported to have antihepatocellular carcinoma activity in previous studies. In one of these studies, Yan et al. (2010) found that oleanolic acid induced apoptosis in four human liver cancer cell lines (HepG2, Hep3B, Huh7 and HA22T) [15]. In another study, it was reported that pectolinarigenin exhibited cytotoxic activity with $\mathrm{IC}_{50}$ value of $>100 \mu \mathrm{g} / \mathrm{mL}$ against hepatocellular carcinoma Huh-7D12 cell line [16]. Also, Bao et al. (2018) demonstrated that taraxasterol inhibited the growth of human liver cancer line (HepG2) [17]. In our current study, taraxasterol with $\mathrm{IC}_{50}$ value of $178.57 \mu \mathrm{g} / \mathrm{mL}$ against HepG2 cell line, oleanolic acid with $\mathrm{IC}_{50}$ value of $229.36 \mu \mathrm{g} / \mathrm{mL}$ against HepG2 cell line and pectolinarigenin with $\mathrm{IC}_{50}$ values of 427.35 and 188.47 $\mu \mathrm{g} / \mathrm{mL}$ against HepG2 and Hep3B cell lines showed an anticancer activity. These results were found to be compatible with previous studies and confirm the anticancer activities of these compounds.

\section{CONCLUSION}

As a result, it can be said that among the all tested compounds, jaceosidin and 3'-O- methyleupatorin have the best inhibitory activity against hepatocellular carcinoma cells. However, further investigation, different anticancer activity methods such as XTT, WST-1 and Real Time Cell Analyzer System, is required to fully reveal antihepatocellular carcinoma effects of the compounds. It may also be useful to investigate the anticancer activity of these compounds on different cancer lines.

\section{MATERIALS AND METHODS}

\subsection{Plant material, extraction and isolation}

Anticancer activities of the compounds previously isolated by Sen et al. (2017) [12] were investigated in this study. Detailed information about where the aerial parts of C. kilaea were collected [13], obtaining chloroform extract [13], isolation of compounds from this extract [12] and determination of their structures of taraxasterol [12, 13, 34-37], salvigenin [12, 38, 39], 3'-O-methyleupatorin [12, 38, 39], oleanolic acid [12, 40, $41]$, jaceosidin $[12,38,39]$, and pectolinarigenin $[12,38,39,42]$ was explained in the previous studies. In this aforementioned study, taraxasterol, salvigenin, 3'-O-methyleupatorin, oleanolic acid, jaceosidin and pectolinarigenin were isolated as secondary metabolites from the chloroform extract of $C$. kilaea and coded as CK1, CK2, CK3, CK4, CK5, CK6 respectively, in this study (Figure 1).

\subsection{Cell culture}

The human liver cancer cell lines HepG2 and Hep3B were obtained from the ATCC and maintained according to the recommendations of the ATCC at $37^{\circ} \mathrm{C}$ and $5 \% \mathrm{CO} 2$ in complete DMEM, supplemented with $100 \mathrm{U} / \mathrm{mL}$ penicillin $\mathrm{G}, 100 \mu \mathrm{g} / \mathrm{mL}$ streptomycin and $10 \% \mathrm{FBS}$.

NIH3T3 fibroblasts were cultured using DMEM (low glucose) supplemented with $100 \mathrm{U} / \mathrm{mL}$ penicillin G, $100 \mu \mathrm{g} / \mathrm{mL}$ streptomycin and 10\% FBS. Subsequent to reaching confluence, the HepG2, Hep3B and NIH3T3 cells were detached using $0.25 \%$ trypsin-EDTA and $1 \times 10^{4}$ cells were seeded into the same complete medium. 


\subsection{In vitro cell proliferation assay}

Cell proliferation was assessed using the MTT assay [43-45]. Cells $\left(1 \times 10^{4}\right.$ number/well) were seeded in triplicate in a 96-well plate and treated with varying concentrations of the compounds. Survival of the control groups (without drug exposure) were defined as $100 \%$. The Cell viability were evaluated by Vybrant ${ }^{\circledR}$ MTT Cell Proliferation Assay Kit at the end of treatment for $24 \mathrm{~h}, 20 \mu \mathrm{L}$ of MTT $(5 \mathrm{mg} / \mathrm{mL}$ in PBS) was added to each well and incubated for another $4 \mathrm{~h}$. The supernatant in each well was replaced with 100 $\mu \mathrm{L}$ of SDS to solubilize the MTT formazan precipitate and optical density (OD) was measured immediately at $570 \mathrm{~nm}$ using Epoch Microplate Spectrophotometer.

Acknowledgements: The authors would like to thank Dr. Gizem Bulut for her help in identification of the plant material. This work was supported by the Research Fund of the University of Marmara [SAG-C-DRP-150218-0041].

Author contributions: Concept - T.S., A.S., L.B., A.S.; Design - T.S., A.S., A.S.; Supervision - T.S., L.B., A.S.; Resources - T.S., A.S., L.B., A.S.; Materials - T.S., A.S., L.B., A.S.; Data Collection and/or Processing - T.S., A.S., A.S.; Analysis and/or Interpretation - T.S., A.S., L.B., A.S.; Literature Search - T.S., A.S., L.B., A.S.; Writing - T.S., A.S., L.B., A.S.; Critical Reviews - T.S., A.S., L.B., A.S.

Conflict of interest statement: The authors declared no conflict of interest.

\section{REFERENCES}

[1] Grizzi F, Chiriva-Internati M. Cancer: Looking for simplicity and finding complexity. Cancer Cell Int. 2006; 6(1): 17. [CrossRef]

[2] El-Serag HB, Rudolph KL. Hepatocellular carcinoma: epidemiology and molecular carcinogenesis. Gastroenterology. 2007; 132(7): 2557-2576. [CrossRef]

[3] Prasad KN. Multiple dietary antioxidants enhance the efficacy of standard and experimental cancer therapies and decrease their toxicity. Integr Cancer Ther. 2004; 3(4): 310-322. [CrossRef]

[4] Purnamasari R, Winarni D, Permanasari AA, Agustina E, Hayaza S, Darmanto W. Anticancer activity of methanol extract of Ficus carica leaves and fruits against proliferation, apoptosis, and necrosis in Huh7it cells. Cancer Inform. 2019; 18: 1-7. [CrossRef]

[5] Balunas MJ, Kinghorn AD. Drug discovery from medicinal plants. Life Sci. 2005; 78(5): 431-441. [CrossRef]

[6] Orabi KY, Sary HG, Ayoub NA, Singab ANB. Isolation of a bioactive guaianolide from Centaurea aegyptiaca ethanol extract. Planta Medica. 2013; 79(10): PN62. [CrossRef]

[7] Sekerler T, Sen A, Bitis L, Sener A, Anticancer, antioxidant and anti-inflammatory activities of chloroform extracts from some Centaurea species. Proceedings. 2018; 2(25): 1542. [CrossRef]

[8] Ahmed SA, Kamel EM. Cytotoxic activities of flavonoids from Centaurea scoparia. Sci World J. $2014 ; 2014: 1-7$. [CrossRef]

[9] Chicca A, Tebano M, Adinolfi B, Ertugrul K, Flamini G, Nieri P. Antiproliferative activity of aguerin B and a new rare nor-guaianolide lactone isolated from the aerial parts of Centaurea deflexa. Eur J Med Chem. 2011; 46: 30663070. [CrossRef]

[10] Csapi B, Hajdu Z, Zupko I, Berenyi A, Forgo P, Szabo P, Hohmann J. Bioactivity-guided isolation of antiproliferative compounds from Centaurea arenaria. Phytother Res. 2010; 24: 1664-1669. [CrossRef]

[11] Csupor-Löffler B, Hajdu Z, Rethy B, Zupko I, Mathe I, Redei T, Falkay G, Hohmann J. Anti-proliferative activity of Hungarian Asteraceae species against human cancer cell lines. Part II. Phytother Res. 2009; 23: 1109-1115. [CrossRef]

[12] Sen A, Ozbas TS, Bitis L. Bioactivity-guided isolation of anti-proliferative compounds from endemic Centaurea kilaea. Pharm Biol. 2017; 55(1): 541-546. [CrossRef]

[13] Sen A, Ozbas ST, Akbuga J, Bitis L. In vitro antiproliferative activity of endemic Centaurea kilaea Boiss. against human tumor cell lines. Clin Exp Health Sci. 2015; 5: 149-153.

[14] Russo A, Cardile V, Graziano AC, Rigano D, Aktumsek A, Zengin G, Senatore F. Effect of three Centaurea species collected from central anatolia region of Turkey on human melanoma cells. Nat Prod Commun. 2016; 11(3): 275278. [CrossRef] 
[15] Yan S-1, Huang C-y, Wu S-t, Yin M-c. Oleanolic acid and ursolic acid induce apoptosis in four human liver cancer cell lines. Toxicol In Vitro. 2010; 24: 842-848. [CrossRef]

[16] Bonesi M, Tundis R, Deguin B, Loizzo MR, Menichini F, Tillequin F, Menichini F. In vitro biological evaluation of novel 7-O-dialkylaminoalkyl cytotoxic pectolinarigenin derivatives against a panel of human cancer cell lines. Bioorg Med Chem Lett. 2008; 18: 5431-5434. [CrossRef]

[17] Bao T, Ke Y, Wang Y, Wang W, Li Y, Wang Y, Kui X, Zhou Q, Zhou H, Zhang C, Zhou D, Wang L, Xiao C. Taraxasterol suppresses the growth of human liver cancer by upregulating Hint1 expression. J Mol Med. 2018; 96: 661-672. [CrossRef]

[18] De Stefanis D, Scimè S, Accomazzo S, Catti A, Occhipinti A, Bertea CM, Costelli P. Anti-proliferative effects of an extra-virgin olive oil extract enriched in ligstroside aglycone and oleocanthal on human liver cancer cell lines. Cancers. 2019; 11(11): 1640. [CrossRef]

[19] Davis PH, Flora of Turkey and the East Aegean Islands, Edinburgh University Press, Edinburgh 1975.

[20] Davis PH, Mill RR, Tan K, Flora of Turkey and the East Aegean Islands, Edinburgh University Press, Edinburgh 1988.

[21] Güner A, Ozhatay N, Ekim T, Baser KHC, Flora of Turkey and the East Aegean Islands, Edinburgh University Press, Edinburgh 2000.

[22] Bensouici C, Kabouche A, Kabouche Z, Touzani R, Bruneau C. Sesquiterpene lactones and flavonoids from Centaurea foucauldiana. Chem Nat Compd. 2012; 48: 510-511. [CrossRef]

[23] Baytop T, Türkiye'de Bitkilerle Tedavi (Treatment with plants in Turkey), Nobel Trp Kitapevi, Istanbul 1999 (In Turkish)

[24] Tuzlacı E, İşbilen DFA, Bulut G. Turkish folk medicinal plants, VIII:Lalapaşa (Edirne). Marmara Pharm J. 2010; 14: 47-52.

[25] Bahmani F, Esmaeili S, Bashash D, Dehghan-Nayeri N, Mashati P, Gharehbaghian A. Centaurea albonitens extract enhances the therapeutic effects of vincristine in leukemic cells by inducing apoptosis. Biomed Pharmacother. 2018; 99: 598-607. [CrossRef]

[26] El-Najjar N, Dakdouki S, Darwiche N, El-Sabban M, Saliba N A, Gali-Muhtasib H. Anti-colon cancer effects of salograviolide a isolated from Centaurea ainetensis. Oncology reports. 2008; 19(4): 897-904. [CrossRef]

[27] Alper M, Gunes H. The anticancer and anti-inflammatory effects of Centaurea solstitialis extract on human cancer cell lines. Turk J Pharm Sci. 2019; 16(3): 273-281. [CrossRef]

[28] Yırtıcı Ü, Göger F, Sarimahmut M, Ergene A. Cytotoxic and apoptotic effects of endemic Centaurea fenzlii Reichardt on the MCF-7 breast cancer cell line. Turk J Biol. 2017; 41(2): 370-377.

[29] Khan M, Rasul A, Yi F, Zhong L, Ma T. Jaceosidin induces p53-dependent g2/m phase arrest in u87 glioblastoma cells. Asian Pac J Cancer Prev. 2011; 12: 3235-3238.

[30] Lv W, Sheng X, Chen T, Xu Q, Xie X. Jaceosidin induces apoptosis in human ovary cancer cells through mitochondrial pathway. J Biomed Biotechnol. 2008; 2008: 1-6. [CrossRef]

[31] Li Y, Tan Y. Jaceosidin inhibits proliferation of human bladder cancer T24 cells through induction of cell cycle arrest and apoptosis. Bangladesh J Pharmacol. 2013; 8: 349-356. [CrossRef]

[32] Alwahibi LH, Abdel-Mageed WM, Abdelkader MSA, Bayoumi SAL, Basudan OA, El-Gamal AA, Bolla K. Sesquiterpene Lactones and Flavonoids from Artemisia sieberi. Int J Pharmacogn Phytochem Res. 2016; 8(4): 639-644.

[33] Kanadaswami C, Lee L-T, Lee P-PH, Hwang J-J, Ke F-C, Huang Y-T, Lee M-T. The antitumor activities of flavonoids. In Vivo. 2005; 19(5): 895-909.

[34] Khalilov LM, Khalilova AZ, Shakurova ER, Nuriev IF, Kachala VV, Shashkov AS, Dzhemilev UM. PMR and 13C NMR spectra of biologically active compounds. XII. Taraxasterol and its acetate from the aerial part of Onopordum acanthium. Chem Nat Compd. 2003; 39: 285-288. [CrossRef]

[35] Mouffok S, Haba H, Lavaud C, Long C, Benkhaled M. Chemical constituents of Centaurea omphalotricha Coss. \& Durieu ex Batt. \& Trab. Rec Nat Prod. 2012; 6: 292-295.

[36] Shakeri A, Ahmadian M. Phytochemical studies of some terpene compounds in roots of Cynara scolymus. Intl J Farm Alli Sci. 2014; 10: 1065-1068.

[37] Yekta MM, Alavi SHR. New triterpenoids from Peucedanum ruthenicum. Iran J Pharm Sci. 2008; 4: 289 -294. 
[38] Mabry TJ, Markham KR, Thomas MB, The systematic identification of flavonoids, Springer-Verlag, Berlin 1970.

[39] Salan Ü, Topçu G, Öksüz S. Flavonoids of Centaurea kilaea and C. salonitana. J Fac Pharm Istanbul. 2001; 34 : 55-61.

[40] Irungu BN, Orwa JA, Gruhonjic A, Fitzpatrick PA, Landberg G, Kimani F, Midiwo J, Erdélyi M, Yenesew A. Constituents of the roots and leaves of Ekebergia capensis and their potential antiplasmodial and cytotoxic activities. Molecules 2014; 19: 14235-14246. [CrossRef]

[41] Martins D, Carrion LL, Ramos DF, Salomé KS, Almeida da Silva PE, Barison A, Nunez CV. Triterpenes and the antimycobacterial activity of Duroia macrophylla Huber (Rubiaceae). BioMed Res Int. 2013; 2013: 1-7. [CrossRef]

[42] Chacón-Morales P, Amaro-Luis JM, Bahsas A. Isolation and characterization of (+)-mellein, the first isocoumarin reported in Stevia genus. Av Quím. 2013; 8: 145-151.

[43] Beekman AC, Barentsen AR, Woerdenbag HJ, Uden WV, Pras N. Stereochemistry-dependent cytotoxicity of some artemisinin derivatives. J Nat Prod. 1997; 60: 325-330. [CrossRef]

[44] Woerdenbag HJ, Meijer C, Mulder NH. Evaluation of in vitro cytotoxicity of some sesquiterpene lactones on human lung carcinoma cell line using the fast green dye exclusion assay. Planta Med. 1986; 2: 112-114. [CrossRef]

[45] Mosmann T. Rapid colorimetric assay for cellular growth and survival: application to proliferation and cytotoxicity assays. J Immunol Methods. 1983; 65: 55-63. [CrossRef]

This is an open access article which is publicly available on our journal's website under Institutional Repository at http://dspace.marmara.edu.tr. 